\title{
Nursing
}

\section{A QUASI EXPERIMENTAL STUDY TO ASSESS THE EFFECTIVENESS OF STRUCTURED TEACHING PROGRAM ON KNOWLEDGE REGARDING UMBILICAL CORD BLOOD BANKING AMONG BASIC B.SC. NURSING STUDENTS OF SELECTED NURSING COLLEGE IN JAMMU}

\author{
Mr. Arshid Nazir \\ Shah \\ M.Sc. Pediatric Nursing, DNA Tutor, Government Nursing College, Gandhi Nagar, \\ Jammu.
}

\section{ABSTRACT}

Until recently umbilical cord and the placenta was discarded as medical waste after delivery. Hematopoietic stem cells(HSCs) are multi-potent stem cells, derived from bone marrow and peripheral blood. These HSCs are also present in umbilical cord blood. Umbilical cord blood (UCB) is a good source of hematopoietic stem cells that is equivalent to those found in the bone marrow. After delivery, umbilical cord blood can be collected and cryopreserved which can be used later. The stem cells in cord blood can grow into any type of cell especially blood and immune system cells, due to its multi-potent nature. These HSC are accepted method of treatment for various blood cell disorders, cancers, genetic diseases, immune disorders and metabolic disorders. Clinical trials are underway for neurological disorders,diabetes, auto-immune disorders and for some cardio vascular problems. So far worldwide more than 30,000 cord blood transplantations were done successfully.

AIM: Aim of the study is to enhance the knowledge of basic B.Sc. Nursing students regarding umbilical cord blood banking who are studying in Rajiv Gandhi College of Nursing, Jammu.

MATERIALS AND METHODS:An evaluative approach with one group pre-test, post-test design was used for the study. The sample consisting of 50 Basic B.Sc. Nursing students, they were chosen by convenient sampling technique. The study was conducted at Rajiv Gandhi College of Nursing, Jammu. The data was collected prior and after the structured teaching program by a structured questionnaire.

RESULTS AND CONCLUSION: The overall mean knowledge score is 23.96 obtained by the subject in post-test was higher than mean knowledge score 9.42 obtained in pre-test and with the improvement score as 14.54 . The results of the study revealed that the structured teaching program was significantly effective in improving the knowledge of students regarding umbilical cord blood banking. Hence the study concluded that the improved knowledge regarding umbilical cord blood bankinghelps the students to grow constantly, to be more advanced in medical research like what are the different benefits and use of stem cells derived from umbilical cord blood and thus attempts will be made by these students to educate the society about umbilical cord blood banking through different methods.

KEYWORDS : Structured Teaching Program, Effectiveness, Knowledge, Nursing College, Umbilical Cord Blood Banking.

\section{INTRODUCTION}

"NOBODY CAN GO BACK AND START A NEW BEGINNING, BUT ANYONE CAN START TODAY AND MAKE A NEW ENDING." (MARIAROBINSON)

On the day of birth of baby, parents will probably overcome with the vision of future with their child's first smile, steps and life milestones. Their child over becoming seriously ill, will probably be the last thing on their mind. But some parents do consider the possibility that a serious illness might someday affect their child and they make a choice on the day their baby is born that might impact the future health of that child or even their other children by deciding to bank their newborn's cord blood.

Umbilical cord blood is rich in stem cells, which are the building of the blood and the immune system. These biologically unique cells have the ability to develop into other cell types within the body. Stem cells collected from the umbilical cord have the ability to replace bone marrow and to produce various blood and immune cells.

In brief, the procedure of the umbilical cord blood banking involves the cutting and clamping of the umbilical cord.A specialized blood bag is then bar-coded for collection of cord blood. For the collection step, the needle of the blood bag is inserted into the umbilical vein and the bag is held at a lower level in order to allow the blood to drain into the bag. Stem cells are then harvested from the cord blood and then stored in cryogenic preservation vials at below $170^{\circ} \mathrm{C}$ in liquid nitrogen. Molecular tests are conducted for tissue(Human leukocyte antigen) typing.

Advancement in medical research has established the use of cord blood based stem cells in the treatment of more than 45 diseases, especially in the treatment of deadly diseases like leukemia, lymphoma etc. currently research in the use of stem cells to treat more than 85 diseases such as diabetes, heart attack, stroke, spinal cord injuries, blindness etc. is being undertaken. There has been a completely new wave of research trials involving umbilical stem research that has swept through the nation.

\section{NEED FOR THE STUDY}

Cord blood is a biological insurance against diseases. The umbilical cord blood is a rich source of stem cells that can be derived from two sources: cord blood and cord tissue. The stem cells derived from the cord blood are called hematopoietic stem cells, these have immense potential in curing blood related disorders like blood cancer, thalassemia etc. The cells derived from the cord tissue are called mesenchymal stem cells, these can be useful in treating tissue related disorders of heart, bone, spinal cord, etc. Investigators also speculate that cord blood stem cells could be used to revitalize a damaged immune system, making them nearby as versatile as embryonic stem cells for treating such immune disorders as type 1 diabetes and rheumatoid arthritis.

As stem cell therapy breaks new ground and stem cells derived from the umbilical cord is gaining momentum thus so called umbilical cord blood banking is being touted as insurance for life. In India there are approximately 72000 births daily, which results in discarding 72000 umbilical cord a day. The storage of stem cell rich blood derived from these umbilical cords can prove to be the best possible insurance against life threatening diseases.

Kang et al have reported the use of cord blood stem cells to restore 'feeling and mobility' to a spinal cord injury patient, who had been a paraplegic for 19 years due to an accident. Forty-one days after stem cells transplantation, 'test' showed the regeneration of the spinal cord at the site and below it.

Laughlin et al conducted a study of 68 patients with leukemia or with other blood disorders.Most of the patients received transplants of umbilical cord cells from the "mismatched" cord blood cells. Only $20 \%$ of the patients developed severe immunity problems compared to $55 \%$ of the patients who developed such problems after receiving perfectly matched bone marrow. ${ }^{8}$ Therefore, I as a researcher felt that above studies and other observations were pathway for me to select this problem statement.

\section{OBJECTIVES}

1. To assess the pretest knowledge score on umbilical cord blood banking among Basic B.Sc. Nursing students.

2. To assess the post-test knowledge score on umbilical cord blood banking among Basic B.Sc. Nursing students.

3. To assess the effectiveness of STP on knowledge score of umbilical cord blood banking among Basic B.Sc. Nursing students.

4. To find out the association between pretest knowledge score of

Submitted : 12 $^{\text {th }}$ June, $2018 \quad$ Revised : $2^{\text {nd }}$ July, 2019 
Volume-9 | Issue-11 | November - 2019 | PRINT ISSN No. 2249 - 555X | DOI : 10.36106/ijar

Basic B.Sc. Nursing students and selected demographic variables.

\section{HYPOTHESIS}

1. H1: There will be a significant difference between the mean pretest and posttest knowledge score on umbilical cord blood banking among Basic B.Sc. Nursing students.

2. H2: There will be significant association between the pretest knowledge score of the Basic B.Sc. Nursing students and demographic variables.

\section{MATERIALS AND METHODS}

The research design used in this study was one group pre-test and posttest in nature. The study was conducted at Rajiv Gandhi College of Nursing Jammu. The sample of 50 Basic B.Sc. Nursing students on the basis of inclusion and exclusion criteria were selected by using convenient, non-probability sampling technique. The tool used for the study was structured knowledge questionnaire which consists of section I (include demographic data, consisting 09 items i.e., age, religion, sex, family income,type of family, previous education of the student, family location, place of stay and marital status) and section II (consisting 30 questions related to knowledge assessment regarding umbilical cord blood banking). The content validity of structured knowledge questionnaire was ensured by submitting the tool to the experts in the field of Medical Surgical Nursing, Community Health Nursing, Obstetrical and Gynecological Nursing etc. A pilot study was conducted on $10 \%$ of total sample size in Rajiv Gandhi College of Nursing Jammu. Reliability of tool was established by Karl Pearson's co-relation coefficient formula. The reliability of tool was calculated and it was found to be $\mathrm{r}=0.89^{\prime}$ which indicate that the tool was reliable.

\section{RESULTS AND FINDINGS}

In this study, 50 students were participated. The data and the findings were entered in a master data sheet followed by the analysis and interpretation by using frequency, percentage, mean, median and standard deviation according to the objectives of the study. The analysis of data is organized and presented under following headings:

Section - I Characteristics of sample object

Section - II Effectiveness of Structured teaching program

Section-III Association between pretest knowledge score and selected demographic variables.

Section-I: Characteristics of sample object

Table 1: Shows frequency and percentage distribution of sample on the basis of age, religion, sex, family income per month, types of family, previous education of the student, family location, place of stay and marital status.

\begin{tabular}{|c|c|c|c|c|}
\hline S.No. & $\begin{array}{c}\text { Demographic } \\
\text { variables }\end{array}$ & $\begin{array}{l}\text { Population } \\
\text { particulars }\end{array}$ & $\begin{array}{l}\text { Frequency } \\
\text { percentage }\end{array}$ & $\begin{array}{c}\text { Frequency } \\
(\mathbf{N}=\mathbf{5 0})\end{array}$ \\
\hline \multirow[t]{3}{*}{1.} & \multirow[t]{3}{*}{ Age } & $18-20$ years & $78.0 \%$ & 39 \\
\hline & & $20-23$ years & $18.0 \%$ & 9 \\
\hline & & Above 23 years & $4.0 \%$ & 2 \\
\hline \multirow[t]{4}{*}{2.} & \multirow[t]{4}{*}{ Religion } & Hindu & $44.0 \%$ & 22 \\
\hline & & Sikh & $4.0 \%$ & 2 \\
\hline & & Muslim & $52.0 \%$ & 26 \\
\hline & & Christian & $0.0 \%$ & 0 \\
\hline \multirow[t]{2}{*}{3.} & \multirow[t]{2}{*}{ Sex } & Male & $44.0 \%$ & 22 \\
\hline & & Female & $56.0 \%$ & 28 \\
\hline \multirow[t]{4}{*}{4.} & \multirow{4}{*}{\begin{tabular}{|l|} 
Family income \\
month
\end{tabular}} & Up to 5000 & $4.0 \%$ & 2 \\
\hline & & $5000-10,000$ & $22.0 \%$ & 11 \\
\hline & & $10,000-15,000$ & $10.0 \%$ & 5 \\
\hline & & Above 15,000 & $64.0 \%$ & 32 \\
\hline \multirow[t]{3}{*}{5.} & \multirow[t]{3}{*}{ Type of family } & Joint family & $44.0 \%$ & 22 \\
\hline & & Nuclear family & $52.0 \%$ & 26 \\
\hline & & Single parent & $4.0 \%$ & 2 \\
\hline \multirow[t]{3}{*}{6.} & \multirow{3}{*}{\begin{tabular}{|l|}
$\begin{array}{l}\text { Previous Edu. Of } \\
\text { the student }\end{array}$ \\
\end{tabular}} & $12^{\text {th }}$ & $90.0 \%$ & 45 \\
\hline & & Degree & $6.0 \%$ & 3 \\
\hline & & Others & $4.0 \%$ & 2 \\
\hline
\end{tabular}

Table 4:

\begin{tabular}{|l|l|l|l|l|l|l|l|}
\hline Knowledge & Mean+ S.D & Mean\% & Range & Mean Diff. & Paired T Test & P value & Table value at 0.05 \\
\hline Pre-test Knowledge & $9.42+3.004$ & 31.40 & $4-17$ & 14.540 & 29.72 & $<0.001$ & 2.01 \\
\hline Post-test Knowledge & $23.96+2.755$ & 79.90 & $19-29$ & & & & \\
\hline \hline
\end{tabular}

\begin{tabular}{|c|c|c|c|c|}
\hline \multirow[t]{2}{*}{7} & \multirow[t]{2}{*}{ Family locations } & Urban & $254.0 \%$ & 27 \\
\hline & & Rural & $46.0 \%$ & 23 \\
\hline \multirow[t]{3}{*}{8.} & \multirow[t]{3}{*}{ Place of stay } & Home & $24.0 \%$ & 12 \\
\hline & & Hostel & $70.0 \%$ & 35 \\
\hline & & Relatives home & $6.0 \%$ & 3 \\
\hline \multirow[t]{5}{*}{9.} & \multirow[t]{5}{*}{ Marital status } & Married & $4.0 \%$ & 2 \\
\hline & & Unmarried & $94.0 \%$ & 47 \\
\hline & & Separated & $2.0 \%$ & 1 \\
\hline & & Divorced & $0.0 \%$ & 0 \\
\hline & & Widow & $0.0 \%$ & 0 \\
\hline
\end{tabular}

Section II: Effectiveness Structured teaching program.

Table 2: Shows frequency, percentage distribution and mean of pre-test knowledge score.

\begin{tabular}{|c|c|c|c|}
\hline $\begin{array}{c}\text { Pre-test } \\
\text { knowledge score }\end{array}$ & $\begin{array}{c}\text { Level of } \\
\text { knowledge }\end{array}$ & $\begin{array}{c}\text { Knowledge } \\
\text { score } \\
\text { (Frequency, } \\
\text { N= 50) }\end{array}$ & $\begin{array}{c}\text { Frequency } \\
\text { percentage }\end{array}$ \\
\cline { 2 - 4 } & Inadequate $(0-10)$ & 30 & $60 \%$ \\
\cline { 2 - 4 } & Moderate (11-20) & 20 & $40 \%$ \\
\cline { 2 - 4 } & Adequate (21-30) & 0 & $0 \%$ \\
\cline { 2 - 4 } & Total & $\mathbf{5 0}$ & $\mathbf{1 0 0 \%}$ \\
\hline
\end{tabular}

Figure 1:

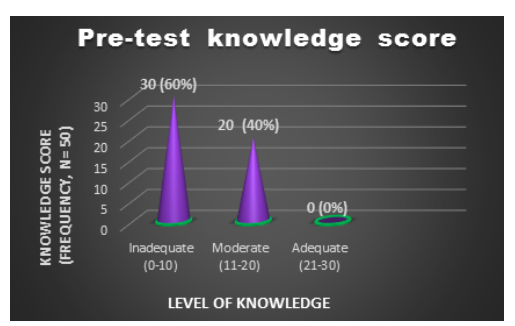

The data in table $\mathbf{2}$ and in figure $\mathbf{1}$ showed that the knowledge regarding umbilical cord blood bankingin Basic B.Sc. Nursing students of RGCN is reflected by pre-test score and it is observed that most of the subjects $30(60 \%)$ have inadequate knowledge and $20(40 \%)$ have moderate knowledge and no one in pre-test having adequate knowledge.

Table 3: Shows frequency, percentage distribution and mean of post-test knowledge score.

\begin{tabular}{|c|c|c|c|}
\hline $\begin{array}{c}\text { Post-test } \\
\text { knowledge } \\
\text { score }\end{array}$ & Level of knowledge & $\begin{array}{c}\text { Knowledge score } \\
\text { (Frequency, N= 50) }\end{array}$ & $\begin{array}{c}\text { Frequency } \\
\text { percentage }\end{array}$ \\
\cline { 2 - 4 } & Inadequate (0-10) & 0 & $0 \%$ \\
\cline { 2 - 4 } & Moderate (11-20) & 10 & $20 \%$ \\
\cline { 2 - 4 } & Adequate (21-30) & 40 & $80 \%$ \\
\cline { 2 - 4 } & Total & $\mathbf{5 0}$ & $\mathbf{1 0 0 \%}$ \\
\hline
\end{tabular}

\section{Figure 2:}

The data in table $\mathbf{3}$ and in figure $\mathbf{2}$ showed that the knowledge regarding umbilical cord blood bankingin Basic B.Sc. Nursing students of RGCN is reflected by post-test score and it is observed that most of the subjects $40(80 \%)$ have adequate knowledge and $10(20 \%)$ have moderate knowledge and $0(0 \%)$ haveinadequate knowledge.

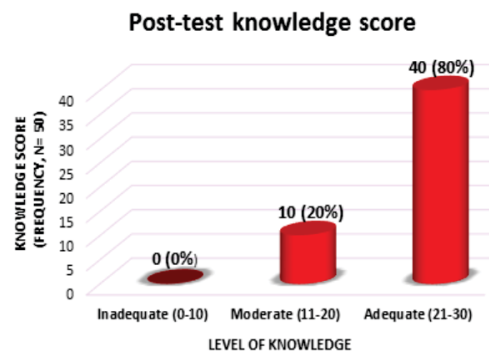


Volume-9 | Issue-11 | November - 2019 | PRINT ISSN No. 2249 - 555X | DOI : 10.36106/ijar The data in Table 4 shows that calculated t-value (29.72) were greater than the table value (t=2.01) at 0.05 level of significance. Hence there is no doubt in confirmation that there is a real significant difference between pre-test and post-test knowledge scores which clearly reflected the effectiveness of structured teaching program.

Section - III: Association between pretest knowledge score and selected demographic variables.

Table 5:

\begin{tabular}{|c|c|c|c|c|c|c|c|c|c|}
\hline Demographic variables & Population particulars & Adequate & Moderate & Inade- quate & Chi test & $P$ value & df & Table value & Result \\
\hline \multirow[t]{3}{*}{ Age } & $18-20$ yrs. & 0 & 16 & 23 & \multirow[t]{3}{*}{1.425} & \multirow[t]{3}{*}{0.491} & \multirow[t]{3}{*}{2} & \multirow[t]{3}{*}{5.991} & \multirow[t]{3}{*}{ Not Significant } \\
\hline & $20-23$ yrs. & 0 & 4 & 5 & & & & & \\
\hline & Above 23 yrs. & 0 & 0 & 2 & & & & & \\
\hline \multirow[t]{4}{*}{ Religion } & Hindu & 0 & 6 & 16 & \multirow[t]{4}{*}{4.895} & \multirow[t]{4}{*}{0.087} & \multirow[t]{4}{*}{2} & \multirow[t]{4}{*}{5.991} & \multirow[t]{4}{*}{ Not Significant } \\
\hline & Sikh & 0 & 2 & 0 & & & & & \\
\hline & Muslim & 0 & 12 & 14 & & & & & \\
\hline & Christian & 0 & 0 & 0 & & & & & \\
\hline \multirow[t]{2}{*}{ Sex } & Male & 0 & 8 & 14 & \multirow[t]{2}{*}{0.216} & \multirow[t]{2}{*}{0.642} & \multirow[t]{2}{*}{1} & \multirow[t]{2}{*}{3.841} & \multirow[t]{2}{*}{ Not Significant } \\
\hline & Female & 0 & 12 & 16 & & & & & \\
\hline \multirow{4}{*}{$\begin{array}{l}\text { Family income/ } \\
\text { month }\end{array}$} & Up to 5000 & 0 & 1 & 1 & \multirow[t]{4}{*}{5.795} & \multirow[t]{4}{*}{0.122} & \multirow[t]{4}{*}{3} & \multirow[t]{4}{*}{7.815} & \multirow[t]{4}{*}{ Not Significant } \\
\hline & $5000-10000$ & 0 & 1 & 10 & & & & & \\
\hline & $10000-15000$ & 0 & 2 & 3 & & & & & \\
\hline & Above 15000 & 0 & 16 & 16 & & & & & \\
\hline \multirow[t]{3}{*}{ Type of family } & Joint family & 0 & 6 & 16 & \multirow[t]{3}{*}{2.652} & \multirow[t]{3}{*}{0.266} & \multirow[t]{3}{*}{2} & \multirow[t]{3}{*}{5.991} & Not Significant \\
\hline & Nuclear family & 0 & 13 & 13 & & & & & \\
\hline & Single parent & 0 & 1 & 1 & & & & & \\
\hline Previous Edu. of & $12^{\text {th }}$ & 0 & 17 & 28 & 1.065 & 0.587 & 2 & 5.991 & Not Significant \\
\hline the student & Degree & 0 & 2 & 1 & & & & & \\
\hline & Others & 0 & 1 & 1 & & & & & \\
\hline Family location & Urban & 0 & 13 & 14 & 1.624 & 0.203 & 1 & 3.841 & Not Significant \\
\hline & Rural & 0 & 7 & 16 & & & & & \\
\hline Place of Stay & Home & 0 & 8 & 4 & 4.683 & 0.096 & 2 & 5.991 & Not Significant \\
\hline & Hostel & 0 & 11 & 24 & & & & & \\
\hline & Relatives home & 0 & 1 & 2 & & & & & \\
\hline Marital status & Married & 0 & 0 & 2 & 2.128 & 0.345 & 2 & 5.991 & Not Significant \\
\hline & Unmarried & 0 & 20 & 27 & & & & & \\
\hline & Separated & 0 & 0 & 1 & & & & & \\
\hline & Divorced & 0 & 0 & 0 & & & & & \\
\hline & Widow & 0 & 0 & 0 & & & & & \\
\hline
\end{tabular}

The data in Table 5 shows that there is no significant association between the pre-test knowledge scores and demographic variables. The calculated chi square values were less than the table value at the 0.05 level of significance. Hence hypothesis $\left(\mathrm{H}_{1}\right)$ was accepted and it can be inferred that STP was effective in increasing the knowledge.

\section{DISCUSSION}

The findings of the study revealed that knowledge level of students regarding umbilical cord blood banking is inadequate and there is a great need to improve this knowledge. In pre-test knowledge score most of the subjects $30(60 \%)$ have inadequate knowledge and $20(40 \%)$ have moderate knowledge and no one in pre-test having adequate knowledge. This reveals that majority of students were having inadequate knowledge, so they need to be educated and informed regarding umbilical cord blood banking.

The findings in post-test score revealed that most of the subjects $40(80 \%)$ have adequate knowledge and $10(20 \%)$ have moderate knowledge and $0(0 \%)$ haveinadequate knowledgeregarding umbilical cord blood banking after implementation of structured teaching program.

The overall mean knowledge score 23.96obtained by the students in post- test was higher than mean knowledge score $\mathbf{9 . 4 2}$ in the pre- test and with the improvement score as 14.42. This indicates that Structured Teaching Program was highly effective in enhancing the knowledge of students regarding umbilical cord blood banking.

From the above findings, it can be concluded that the improved knowledge regarding umbilical cord blood banking helps the students to grow constantly, to be more advanced in medical research like what are the different benefits and use of stem cells derived from umbilical cord blood and thus attempts will be made by these students to educate the society about umbilical cord blood banking through different methods.

\section{RECOMMENDATIONS}

- A Similar study may be repeated on a large sample to generalize the findings.

- A Study may be conducted to evaluate the effectiveness of information book-let regarding umbilical cord blood banking among Basic B.Sc. Nursing students.

- A comparative study can be done to assess the knowledge regarding umbilical cord blood banking between students residing in twodifferent cities.

- A similar study can be conducted with different teaching strategies such as SIM. (Self-instructional module), video assisted teaching.

\section{CONCLUSION}

Based on the findings of the study it can be concluded that there was evident increase in the knowledge scores in all the areas included in the study after administration of STP. Thus it was proved that STP was effective for improving the knowledge regarding umbilical cord blood banking among Basic B.Sc. Nursing students of selected nursing college in Jammu.

\section{REFERENCES}

1. Elizabeth B.Hurlock. Child growth and development. 5th Edition 2006. Tata Mc. GramHill. Pp 1 and 17

2. Banking Your Newborn's Cord Blood. 1995-2010. The Nemours Foundation. http://kidshealth.org/parent/cancer-centre/treatment/cord-blood.html

3. Umbilical Cord Blood Banking. Expectant mothers guide. http://www.expe ctantmothersguide.com/library/national/umblical-cord-blood-banking.html

4. Dhot P.S, VNair, Swarup D, Sirohi D and Ganguli P. Cord Blood Stem Cell Banking and Transplantation. Indian Journal of Pediatrics. Chaudhari Foundation. December 2003; Transplant

5. http://www.cordbloodbanking/wikipedia.com

6. Surbek DV, Visca E, Steinmann C, Tichelli A, Schatt S, Hahn S, Gratwohl A, Holzgreve $\mathrm{W}$. Umbilical cord blood collection before placental delivery during caesarean delivery increases cord blood volume and nucleated cell number available for transplantation. American Journal of Obstetrics and Gynecology. July 2000:183. Issue 1:218-21

7. Hematopoietic stem cells for transplantation into unrelated recipients. The New England Journal of Medicine. July 18,1996; 335: 157-166

8. Vanderson Rocha, Myriam Labopin, et al. Transplants of umbilical cord blood or bone marrow from unrelated donors in adults with acute leukemia. The New England Journal of Medicine. November 2004. Available from: www.nejm.org 